\title{
Effects of Lead and Cadmium on the Seedling of Plants, Brassica Oleracea L, and Abelmoschus Esculentus L.
}

\author{
Thien-Trong-Nguyen Le \\ Hochiminh City University of Technology \\ 268 Ly Thuong Kiet Street, District 10, Hochiminh City, Vietnam \\ Tel: 84-838-639-682 E-mail: trongnguyen_15796@yahoo.com.vn
}

\author{
Thi-Ngoc-Hai Nguyen \\ Hochiminh City University of Technology
}

268 Ly Thuong Kiet Street, District 10, Hochiminh City, Vietnam

Tel: 84-838-639-682Ｅ-mail: ngochai0494@gmail.com

\section{Thanh-Dat Dinh}

Hochiminh City University of Technology

268 Ly Thuong Kiet Street, District 10, Hochiminh City, Vietnam

Tel: 84-838-639-682Ｅ-mail: dinhthanhdat7796@gmail.com

\section{Dinh-Dai Nguyen}

Hochiminh City University of Technology

268 Ly Thuong Kiet Street, District 10, Hochiminh City, Vietnam

Tel: 84-838-639-682Ｅ-mail: dinhdai96@yahoo.com.vn

\author{
Thanh-Son Dao (corresponding author) \\ Hochiminh City University of Technology
}

268 Ly Thuong Kiet Street, District 10, Hochiminh City, Vietnam

Tel: 84-838-639-682Ｅ-mail: dao.son@hcmut.edu.vn

Received: April 21, 2017 Accepted: May 10, 2017

doi:10.5296/emsd.v6i2.11285 URL: https://doi.org/10.5296/emsd.v6i2.11285 


\section{Abstract}

In this study we tested the negative effects of lead $(\mathrm{Pb})$ and cadmium $(\mathrm{Cd})$ at the concentrations of $5-500 \mu \mathrm{g} / \mathrm{L}$ and $1-100 \mu \mathrm{g} / \mathrm{L}$, respectively, on the germination, fresh weight, root and shoot length of broccoli, Brassica oleracea L., and okra, Abelmoschus esculentus L. over the period of 7 days. Two other tests were also conducted as control in which the seeds of these two plants were watered with distilled water only. For each concentration of exposures, 10 seeds were put into a plastic container and nine replicates $(\mathrm{n}=$ 9) for each treatment were prepared. The results revealed slight effects of the metals on the germination of $B$. oleracea and A. esculentus. However, fresh weight of the sprouts was decreased upon metal exposures especially the significant reduction of A. esculentus fresh weight in the $\mathrm{Pb}$ incubations. $\mathrm{Pb}$ slightly affected on the root prolongation of both plants. There was no significant difference on the shoot length of $B$. oleracea in control and $\mathrm{Cd}$ treatments. Furthermore, $\mathrm{Cd}$ tended to stimulate the prolongation of root and inhibit the extension of shoot of $A$. esculentus. Besides, $\mathrm{Cd}(100 \mu \mathrm{g} / \mathrm{L})$ and $\mathrm{Pb}(500 \mu \mathrm{g} / \mathrm{L})$ caused the leaf abnormality in $B$. oleracea. Our results contribute more understanding on the toxicity of $\mathrm{Pb}$ and $\mathrm{Cd}$ at environmentally relevant concentrations on the seedling of plants. Further investigations on the toxicity of other pollutants as well as their mixture on seedling of plants are recommended.

Keywords: Trace metals, Toxicity, Fresh weight, Root and shoot length, Abnormality

\section{Introduction}

In nature, the occurrence of heavy metals is extremely varied in many habitats. They exist in the soil, atmosphere and water environment. The emission of heavy metals into the environment happens through various processes and different paths upon the naturally geographic processes and human activities. Specifically, heavy metals are emitted into the environment through combustion, mining and processing (Jarup 2003). Heavy metals contaminate the ground and surface water through the transportation process in the water currents. The inappropriate process management and treatment of industrial wastewater are also sources of pollution (Tiwaria et al. 2015). Leaking heavy metals into the soil could be occurred through the geochemical processes of weathering of parent materials, mining waste, leaded gasoline and paint, animal manure, sewage sludge, fertilizers, pesticides, irrigation wastewater and atmospheric deposition (Wuana and Okieimen 2011).

Among the heavy metals, lead $(\mathrm{Pb})$ and cadmium $(\mathrm{Cd})$ have been widely monitored and found in water bodies. The concentration of $\mathrm{Cd}$ in the Moon and Shi Rivers, Thailand, exceeded the limits of WHO whereas that of Pb did not (Wongklom, 2016). Jabłońska-Czapla et al. (2016) reported that the Przemsza Biała River in Poland was heavily polluted by $\mathrm{Pb}, \mathrm{Cd}$, and $\mathrm{Zn}$, with the highest concentration of $510 \mu \mathrm{g} \mathrm{Pb} / \mathrm{L}$, more than $1500 \mu \mathrm{g} \mathrm{Zn} / \mathrm{L}$ and $6 \mu \mathrm{g}$ $\mathrm{Cd} / \mathrm{L}$. Similarly, $\mathrm{Pb}$ pollution $(218-330 \mu \mathrm{g} / \mathrm{L})$ and $\mathrm{Cd}$ contamination $(8-12 \mu \mathrm{g} / \mathrm{L})$ were also found in Mahrut River, Iraq (Obaidy et al. 2014). In the surface water in a mining area at Shandong Province, China, the $\mathrm{Cd}$ and $\mathrm{Pb}$ concentrations reached over 190 and $430 \mu \mathrm{g} / \mathrm{L}$, respectively (Ning et al. 2011). In Vietnam, Cd contamination in water from the canal, river, estuary, and swamp from Ca Mau Province was reported and considered as the source of 
metal bio-accumulation for aquatic organisms (Nguyen and Bui 2009). The activities of agriculture, aquaculture and the rapid urbanization in Southern Vietnam have caused surface water become contaminated with metals such as $\mathrm{Pb}, \mathrm{Cu}, \mathrm{Cr}$, As (Strady et al. 2017).

Plants can only use or uptake metals under the form of ions. The trace metals in ion forms are transferred from the soil solution or water into the plant cells through surface roots by root extension, mass-flow, and diffusion (Barber et al. 1963). The absorbance of trace metals could lead to the accumulation of those in plants and then the metals could be transferred into the animals and human beings through the food chain (Nazir et al. 2015). Many trace metals such as $\mathrm{Co}, \mathrm{Cu}, \mathrm{Cr}, \mathrm{Fe}, \mathrm{Mn}, \mathrm{Ni}$ and $\mathrm{Zn}$ are essential for the growth and development of plants because they play important roles in the formation of enzymes, redox reactions. Therefore, they vitally have biochemical function and physiology of plants (WHO/FAO/IAEA 1996). However, when the metal concentrations exceed a certain threshold the metal becomes toxic to plant (Jaishankar 2014). Trace metals at high concentrations could cause the decrease of photosynthesis ability, cell-structural damage, reduction of physical and biochemical activities of plants consequently negative impacts on the growth, the root tip, the absorption of nutrients, the water uptake, and physiological and metabolic processes of plants. The toxic metals such as $\mathrm{Cd}$ and $\mathrm{Pb}$ are greatly toxic even at comparatively low concentration (Sardar 2013).

Li et al. (2005) studied the effects of toxic metals ( $\mathrm{Cd}$ and $\mathrm{Pb})$ on the germination and growth of Arabidopsis thaliana seeds. The authors reported that $\mathrm{Pb}$ did not strongly influence on the germination of seeds, while Cd (at $450 \mathrm{mg} / \mathrm{L}$ ) severely inhibited the germination. Bautista et al. (2013) conducted the exposures of $\mathrm{Cd}$ and $\mathrm{Cr}$ (both at the concentrations of 2.8, 3.9 and $5.6 \mathrm{mg} / \mathrm{L}$ ) to lettuce (Lactuca sativa v. batavia), Swiss chard (Beta vulgaris v. cicla) and spinach (Spinacia olearcea) and found that Cd caused strong impacts on those plants while $\mathrm{Cr}$ only slightly affected on some characteristics such as seed germination, root length and fresh weight. Besides, $\mathrm{Pb}$ and $\mathrm{Cd}$ negatively influenced on seed germination and development of Leucaena leucocephala (Shafiq et al. 2008) The authors observed that the germination significantly reduced when exposed to $75 \mathrm{mg} \mathrm{Pb} / \mathrm{L}$ and $50 \mathrm{mg} \mathrm{Cd} / \mathrm{L}$. The length of stems and roots of the plant was shorter than the control after exposure to $50 \mathrm{mg} / \mathrm{L}$ of $\mathrm{Pb}$ or $\mathrm{Cd}$. The dry weight decreased significantly compared with control samples when irrigated with $\mathrm{Pb}$ and $\mathrm{Cd}$ at the concentration of $25 \mathrm{mg} / \mathrm{L}$ (Shafiq et al. 2008).

The issues of heavy metal pollution are becoming popular in the world, especially in developing countries. Heavy metals are likely to cause high toxicity to plants. Investigations on heavy metal pollution in different environments and the effects of heavy metals to the plants have been conducted. However, the effects of heavy metals (e.g. Pb, Cd) in seedling of plant are not fully understood. The two plants Brassica oleracea and Abelmoschus esculentus, are among the very common vegetable in Southeast Asian. The sprouts of these plants are widely used as food for Vietnamese. Local farmers use surface water, now and then contaminated with trace metals, for watering their crops so there may be potentially negative effects to plants and risk to consumers. Therefore, this research aimed to observe the effects of $\mathrm{Cd}$ and $\mathrm{Pb}$ on the early life stage of B. oleracea and A. esculentus. 


\section{Al Macrothink}

\section{Materials and Methods}

The seeds of Brassica oleracea and Abelmoschus esculentus for the bioassay were purchased from Trang Nong Store, located in District 6, Hochiminh City, Vietnam. The experiment was conducted in the Ecotoxicology Module, Laboratory of Environmental Analysis, Hochiminh City University of Technology. The two metals, $\mathrm{Pb}$ and $\mathrm{Cd}$ in stock solution of $1000 \mathrm{mg} / \mathrm{L}$, for toxicity tests were purchased from the manufacturer, Merck (Germany). Metal concentrations in the experiments were chosen based on the Vietnam regulations 39: 2011 / MONRE - National Technical Regulation on the quality of water used for irrigation.

For experiment, the seeds were exposed to either $\mathrm{Pb}$ or $\mathrm{Cd}$ at four different concentrations: 0 (control), $5 \mu \mathrm{g} \mathrm{Pb} / \mathrm{L}$ (Pb 5), $50 \mathrm{~Pb} \mu \mathrm{g} / \mathrm{L}$ ( $\mathrm{Pb} 50$ ), and $500 \mu \mathrm{g} \mathrm{Pb} / \mathrm{L}$ (Pb 500); $1 \mu \mathrm{g} \mathrm{Cd} / \mathrm{L}$ (Cd 1), $10 \mu \mathrm{g} \mathrm{Cd} / \mathrm{L}(\mathrm{Cd} 10)$ and $100 \mu \mathrm{g} \mathrm{Cd} / \mathrm{L}$ (Cd 100). The experiment was implemented according to the description by Pflugmacher et al. (2007) and Dao et al. (2014) with minor modification. Briefly, for each concentration of exposures, 10 seeds were laid on tissue paper in a plastic container and nine replicates $(n=9)$ for each treatment were prepared at the start of the tests. The seeds were watered daily $(\sim 6 \mathrm{~mL})$ with distilled water only (control) or water containing trace metals at the concentrations mentioned above. During the experiment, the germination of seeds in each exposure was daily recorded. At the second, fourth and seventh 7 days of the experiment, the seeding in three replicates $(n=3)$ of each treatment was weighted, and its root and shoot were measured with a ruler, exactly to $0.1 \mathrm{~mm}$.

Kruskal-Wallis test, Sigmaplot, version 12 was used for evaluation the significant difference on the fresh weight (FW), root and shoot length of the seedling of plants between control and metal exposures.

\section{Results}

\subsection{Influences on the Germination}

Results showed that the germination rate of $B$. oleracea in the control and $\mathrm{Pb}$ exposures was

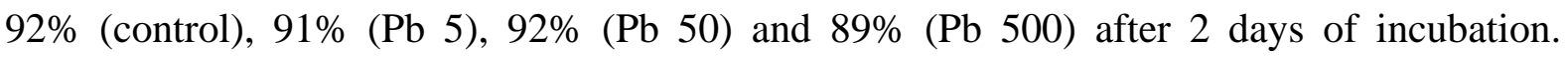
Similarly, after 4 days of experiment, the germination rates of A. esculentus in the control, $\mathrm{Pb}$ $5, \mathrm{~Pb} 50$ and $\mathrm{Pb} 500$ were 95\%, 93\%, 93\% and 88\%, respectively (Table 1). In the tests with $\mathrm{Cd}$, the germination rate of B. oleracea was $93 \%$ in both control and $\mathrm{Cd} 1$, but it was a little decreased to $79 \%$ and $89 \%$ in the exposures to the higher Cd concentrations, $\mathrm{Cd} 10$ and $\mathrm{Cd}$ 100. Interestingly, the concentrations of $1-100 \mu \mathrm{g} / \mathrm{L}$ of $\mathrm{Cd}$ did not reduce the germination rate of $A$. esculentus compared to the control (Table 1). 


\section{Macrothink}

Environmental Management and Sustainable Development

ISSN 2164-7682

2017, Vol. 6, No. 2

Table 1. Seed germination ratio (\%) from the exposures after the first two days for Brassica oleracea and 4 days for Abelmoschus esculentus

\begin{tabular}{|l|c|c|c|c|}
\hline Seeds/ plants & control & $\mathrm{Pb} 5$ & $\mathrm{~Pb} 50$ & $\mathrm{~Pb} 500$ \\
\hline B. oleracea (2 days) & 92 & 91 & 92 & 89 \\
\hline A. esculentus (4 days) & 95 & 93 & 93 & 88 \\
\hline & control & $\mathrm{Cd} 1$ & $\mathrm{Cd} 10$ & $\mathrm{Cd} 100$ \\
\hline B. oleracea (2 days) & 93 & 93 & 79 & 89 \\
\hline A. esculentus (4 days) & 95 & 95 & 95 & 95 \\
\hline
\end{tabular}

\subsection{Influences on the Fresh Weight}

In the experiment on $B$. oleracea exposed to $\mathrm{Cd}$, the average $\mathrm{FW}$ of the seedling after 2 days in the control, Cd 1, Cd 10 and Cd 100 were $13 \mathrm{mg}, 12 \mathrm{mg}, 10 \mathrm{mg}$ and $9 \mathrm{mg}$, respectively. There was a significant difference between the FW in the control and $\mathrm{Cd} 10$ or $\mathrm{Cd} 100$ according to the Kruskal-Wallis test ( $\mathrm{p}<0.05$, Fig. 1). Similar situation was recorded for the FW of the B. oleracea after 4 days of treatment. However, by the end of the test, there was no statistical difference in relation to the FW between the control and Cd exposures (Fig. 1).

In the tests with $\mathrm{Pb}$, the detrimental impact of $\mathrm{Pb} 50$ and $\mathrm{Pb} 500$ on $\mathrm{FW}$ of $B$. oleracea was only observed after two days of experiment ( $\mathrm{p}<0.05$ ). The average FW of one B. oleracea in the control and $\mathrm{Pb}$ exposures ranged $17-20 \mathrm{mg}$, and $40-50 \mathrm{mg}$ after 4 and 7 days of incubation, respectively (Fig. 1). The negative effect of $\mathrm{Pb}$ on $\mathrm{FW}$ of A. esculentus was apparently showed at the highest $\mathrm{Pb}$ concentration $(\mathrm{Pb} 500)$ and after 7 days of incubation in which the FW from the metal exposures was significantly decreased compared to the control (Fig. 1). 

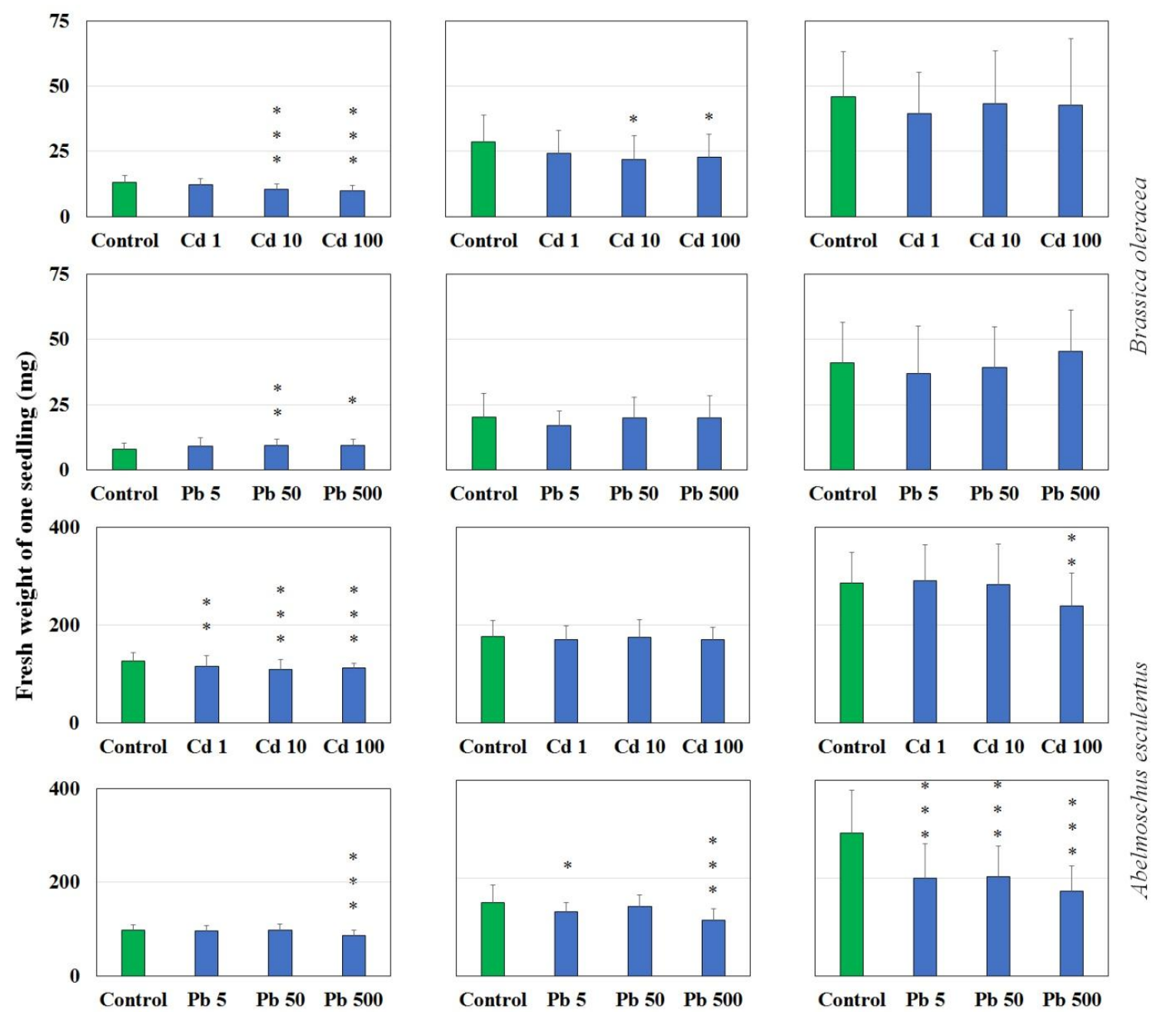

Figure 1. Fresh weight of Brassica oleracea and Abelmoschus esculentus during the experiment. Asterisks indicate the significant difference between the control and metal exposures by Kruskal-Wallis test $(*, \mathrm{p}<0.05 ; * *, \mathrm{p}<0.001 ; * * *, \mathrm{p}<0.001)$

\subsection{Influences on the Root Length}

The root of the seedling was measureable after 4 days of incubation. In the exposures to $\mathrm{Cd}$, the root length of $B$. oleracea in the three concentrations was not significantly different with the control after 4 or 7 days of experiment. The $\mathrm{Cd} 10$ and $\mathrm{Cd} 100$ caused the root length of $A$. esculentus prolong to $30-31 \mathrm{~mm}$, significant longer than the control, $24 \mathrm{~mm}$, after 4 days of testing. However the average length of the root was similar among the control or the three $\mathrm{Cd}$ treatments, $38-46 \mathrm{~mm}$, after 1 week of testing (Fig. 2).

The average root length of $A$. esculentus after 4 days of experiment in the control, $\mathrm{Pb} 5$ and $\mathrm{Pb} 50$ were $19 \mathrm{~mm}$, whereas that in the $\mathrm{Pb} 500$ was $16 \mathrm{~mm}$. After 7 days, the average root length in the control, $\mathrm{Pb} \mathrm{5,Pb} 50$ and $\mathrm{Pb} 500$ was $37 \mathrm{~mm}, 27 \mathrm{~mm}, 34 \mathrm{~mm}$ and $26 \mathrm{~mm}$, respectively (Fig. 2). Statistical results showed that $\mathrm{Pb} 500$ caused the root length of $A$. esculentus significantly shorter than the control after 7 days of experiment (Fig. 2). There was no statistically different of the root length of $B$. oleracea in control and $\mathrm{Pb}$ exposures. 

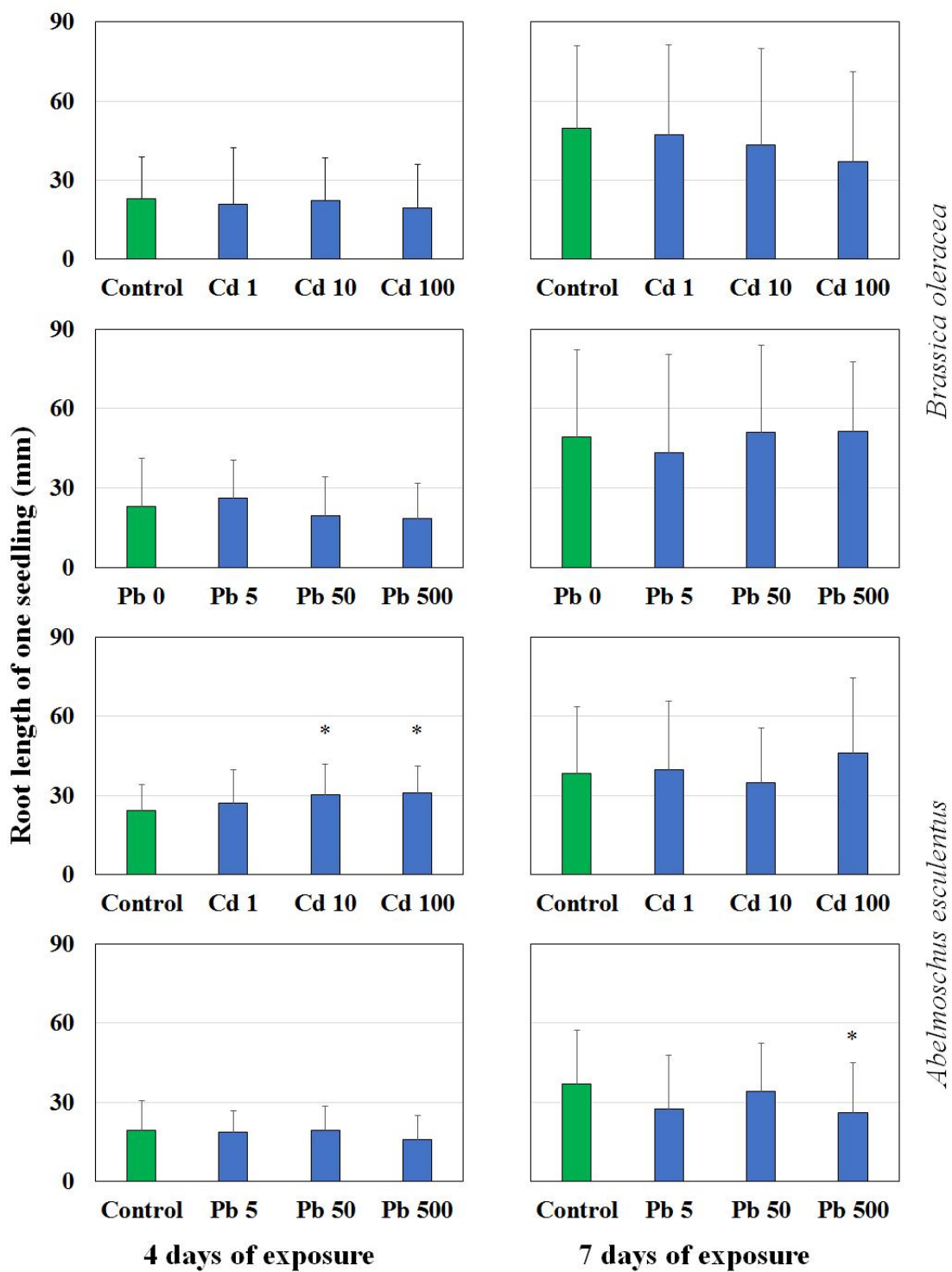

Figure 2. Root length of Brassica oleracea and Abelmoschus esculentus during the experiment. Asterisk indicates the significant difference between the control and metal exposures by Kruskal-Wallis test $\left(^{*}, \mathrm{p}<0.05\right)$

\subsection{Influences on the Shoot Length}

The shoot length of $B$. oleracea was measureable after 4 days of experiment whereas that of A. esculentus was able to be recorded after 7 days of incubation. After 4 experimental days, average shoot length of $B$. oleracea in the control was $13 \mathrm{~mm}$, while the shoot length in the $\mathrm{Cd} 1$ and $\mathrm{Cd} 10$ was $12 \mathrm{~mm}$, and that in the Cd 100 was $10 \mathrm{~mm}$ (Fig 3).

By the end of experiment the average shoot length of B. oleracea in the control, $\mathrm{Cd} 1, \mathrm{Cd} 10$ and $\mathrm{Cd} 100$ was $34 \mathrm{~mm}, 28,26$ and $23 \mathrm{~mm}$, respectively. The among the metal treatments, only shoot length of $B$. oleracea $\mathrm{Cd} 100$ was significantly shorter than the control at 4 and 7 days of exposures (Fig. 3). In the experiment with A. esculentus $\mathrm{Cd} 1$ and all three $\mathrm{Pb}$ exposures inhibited the prolongation of shoot. However, $\mathrm{Cd} 10$ and $\mathrm{Cd} 100$ stimulated the 


\section{Macrothink}

prolongation of the shoot (Fig. 3). Therefore, the shoot length of the two plants, B. oleracea and $A$. esculentus, was regulated differently by the two metals and the concentrations of the metals.
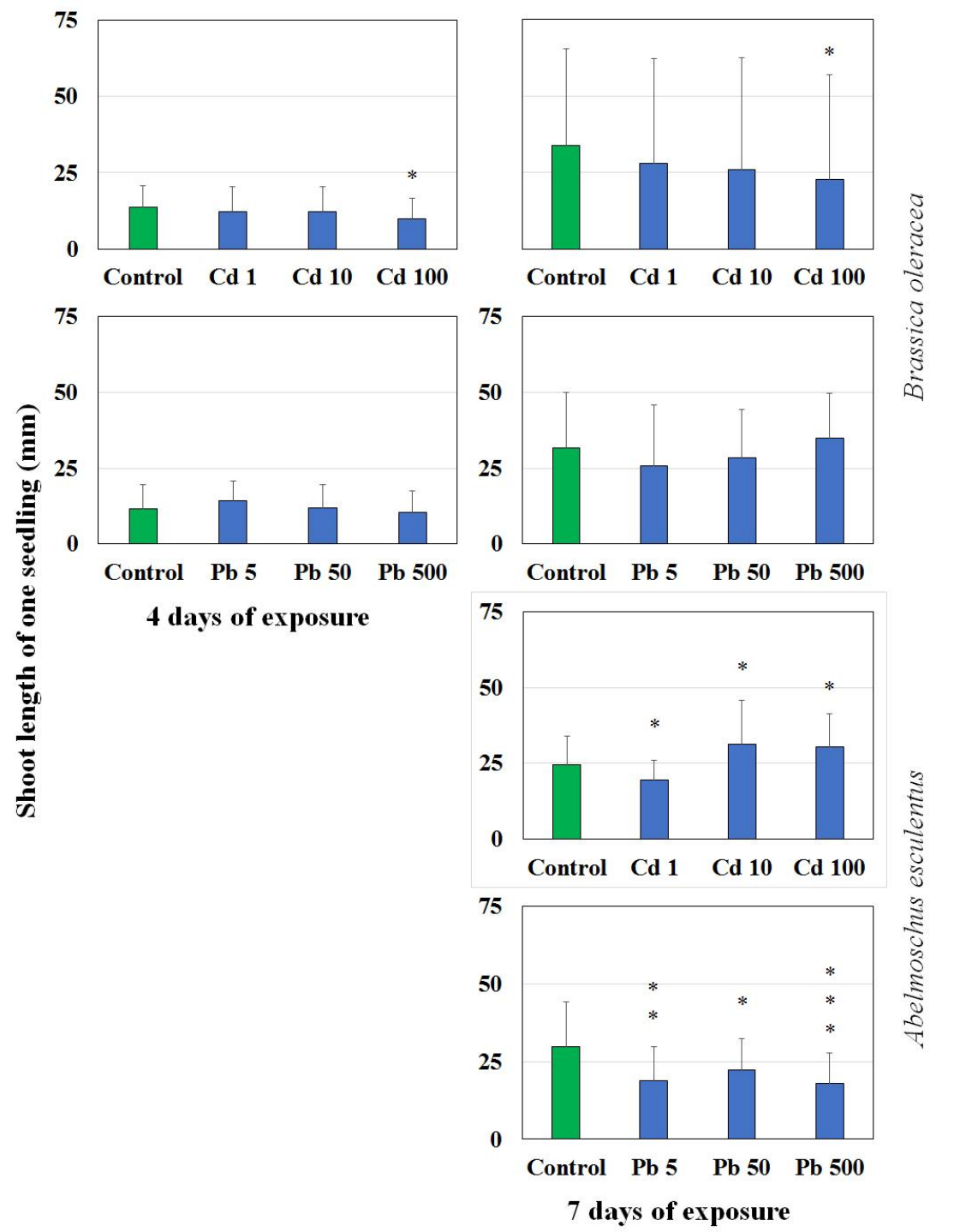

Figure 3. Shoot length of Brassica oleracea and Abelmoschus esculentus during the experiment. Asterisks indicate the significant difference between the control and metal

exposures by Kruskal-Wallis test $\left(^{*}, \mathrm{p}<0.05\right.$ * $\left.^{* *}, \mathrm{p}<0.001 ; * * *, \mathrm{p}<0.001\right)$

\subsection{Influences on Leaf Morphology}

There was no abnormal appearance occurring on the color leaves, shoot and root of $A$. esculentus during the both metal exposures. However, in some of the B. oleracea seedlings, manifestations of black and brown spots on the young leaves from the $\mathrm{Pb}$ and $\mathrm{Cd}$ treatment were observed after 7 days of incubation (Figure 4). 


\section{Macrothink}

A
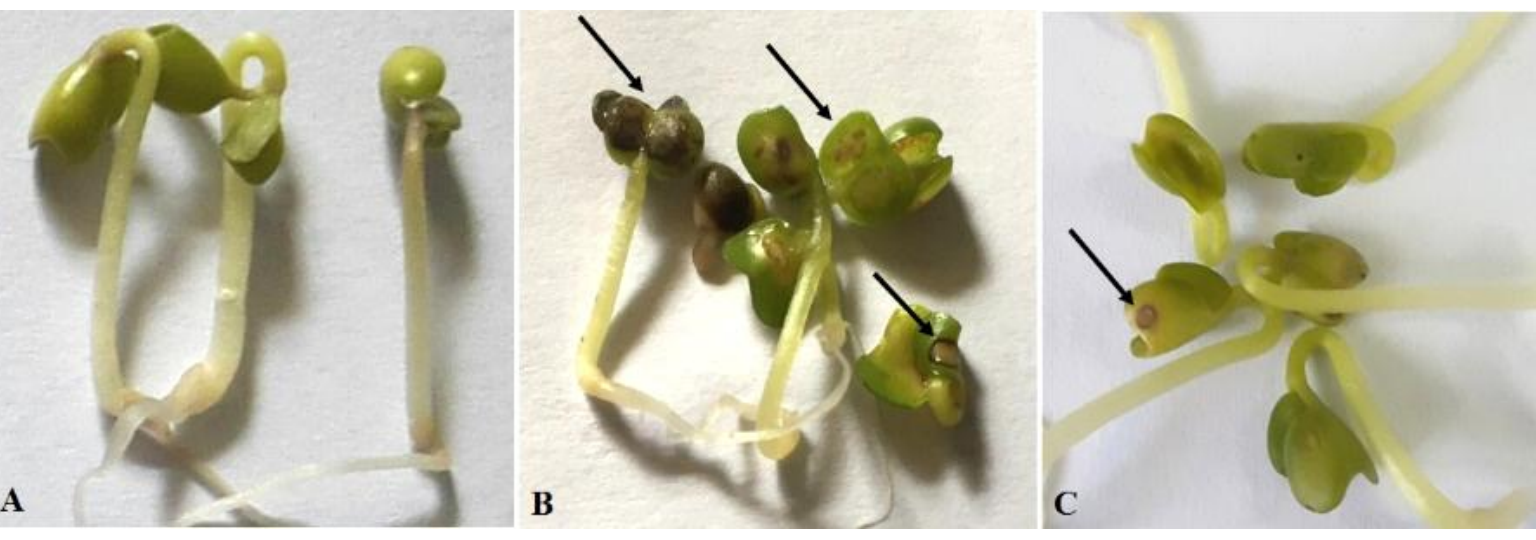

Figure 4. The normality (A, control) and abnormality of young leaves (arrows) of Brassica oleracea upon exposures to $\mathrm{Cd} 100$ (B) and $\mathrm{Pb} 500$ (C)

\section{Discussion}

Generally, the test concentrations of $\mathrm{Pb}$ and $\mathrm{Cd}$ did not cause significant difference on the germination of B. oleracea and A. esculentus. Shafiq et al. (2008) reported the negative effects of $\mathrm{Pb}$ and $\mathrm{Cd}$ on the germination of $L$. leucocephala. However, the metal concentrations used in their study, 75,000 $\mu \mathrm{g} \mathrm{Pb} / \mathrm{L}$ and 50,000 $\mu \mathrm{g} \mathrm{Cd} / \mathrm{L}$, were much higher than those in the current investigation, $500 \mu \mathrm{g} \mathrm{Pb} / \mathrm{L}$ and $100 \mu \mathrm{g} \mathrm{Cd} / \mathrm{L}$. Because the metals at high concentrations can prevent the water uptake consequently germination inhibition, the higher $\mathrm{Pb}$ and $\mathrm{Cd}$ concentrations $(75,000$ and $50,000 \mu \mathrm{g} / \mathrm{L}$, respectively) would properly decrease the germination of $B$. oleracea and $A$. esculentus which needs further investigations.

The FW decrease of $B$. oleracea during the first 4 days on incubation in our study is in line with previous report by Bautista et al. (2013) testing with some plants like lettuce, Swiss chard, and spinach. Trace metals at high concentration could inhibit the water uptake and later the physiological and metabolic processes of plants (Sardar 2013) consequently FW reduction of the seedling in our study. Besides, it could be seen that the toxicity of $\mathrm{Pb}$ to $B$. oleracea and A. esculentus was higher than that of $\mathrm{Cd}$. Also, the tolerance of B. oleracea to $\mathrm{Pb}$ was lower than that of $A$. esculentus. Hence different species would have different sensitivity or tolerance to a certain toxin.

The root of $B$. oleracea was slightly affected when exposed to $\mathrm{Cd}$ at the test concentrations. According to Shafiq et al. (2008), the reduction in the root length exposed to heavy metals may be attributed to the reduction of the root cell tissue. Properly, the used metal concentrations $(1-100 \mu \mathrm{g} \mathrm{Cd} / \mathrm{L}$ and $5-500 \mu \mathrm{g} \mathrm{Pb} / \mathrm{L})$ were not high enough to induce the strong impact on the root length of $B$. oleracea and A. esculentus. However, an investigation on the cell development of the plants upon exposure to $\mathrm{Pb}$ and $\mathrm{Cd}$ is highly suggested to confirm.

Reducing the shoot length of the seedling exposed to heavy metals may be attributed to the reduction of embryonic sprouts' cell tissue and some enzymes contained in the leaf and endosperm. When the activity of the hydrolyzed enzymes is affected, leading to the effects on shoot length of the seedling (Shafiq et al. 2008). Our results also showed that Cd was more 
toxic than $\mathrm{Pb}$ on the development of $\mathrm{B}$. oleracea sprouts. The metals $\mathrm{Pb}$ and $\mathrm{Cd}$ are capable of inhibiting the activity of certain enzymes within the cell leading to disruption of protein synthesis. This may lead to the inhibition of the elongation of root in high metal concentration exposures $(\mathrm{Pb}, \mathrm{Cd})$. This meant the presence of the metals reduced the cell division in the tissue consequently inhibition of the growing process (Sardar 2013). Chemically, the toxic metals $\mathrm{Pb}$ and $\mathrm{Cd}$ have the same valency as $\mathrm{Cu}, \mathrm{Mn}$ and $\mathrm{Zn}$. Therefore, these two toxic metals may outcompete the essential trace metals $(\mathrm{Cu}, \mathrm{Mn}$ and $\mathrm{Zn}$ ) in the bound to active sites of enzymes or cell structures during metabolism processes in cells of plants. Consequently the development during early stage of B. oleracea and A. esculentus would be more or less disordered. Properly the effects of $\mathrm{Pb}$ and $\mathrm{Cd}$ on prolongation of the shoot should be similar to those of the root which needs further investigations on cellular levels to have the detail understanding on this.

$\mathrm{Pb}$ could inhibit the photosynthesis processes by degrading the absorption of essential elements such as $\mathrm{Fe}, \mathrm{Mg}$ (Burzynski 1987). Besides, Cd altered the function of cell membrane by reducing the activity of enzymes involved in fixation of $\mathrm{CO}_{2}$ (De Filippis and Ziegler 1993). These negative effects of the metals could lead to the appearance of brown spots on the leaves. Our observation on the abnormality of young leaves of B. oleracea is in agreement to a previous report by Dao et al. (2014) in which the plants were exposed to the cyanobacterial toxin, microcystin. The detrimental impacts of $\mathrm{Pb}$ and $\mathrm{Cd}$ on the seedling of $B$. oleracea and A. esculentus are evidenced. This means that the toxic metals entered the cells of the plants (during watering with metal-contaminated water). Hence further studies on bioaccumulation of heavy metals in these plants should be studied for the health risk evaluation of local residents who consume the sprout of these plants daily.

\section{Conclusions}

The toxic metals $\mathrm{Pb}$ and $\mathrm{Cd}$ at the test concentrations $(5-500 \mu \mathrm{g} \mathrm{Pb} / \mathrm{L} ; 1-100 \mu \mathrm{g} \mathrm{Cd} / \mathrm{L}$ ) did not significantly reduce the germination of $B$. oleracea and $A$. esculentus. However, the toxic metals strongly affected on FW of the seedling especially potent impact of $\mathrm{Pb}$ on $\mathrm{FW}$ of $A$. esculentus after 7 days of incubation. Cd slightly influenced on root and shoot length of $B$. oleracea while $\mathrm{Pb}$ caused minor change of the root prolongation of the A. esculentus. On the other hand, Cd tended to stimulate the prolongation of root and inhibit the extension of shoot of A. esculentus. The highest concentrations of $\mathrm{Cd}(100 \mu \mathrm{g} / \mathrm{L})$ and $\mathrm{Pb}(500 \mu \mathrm{g} / \mathrm{L})$ induced the abnormality of the young leaves of $B$. oleracea. Further investigations on the toxicity of other pollutants as well as their mixture on seedling of plants are recommended.

\section{Acknowledgement}

This research is funded by Hochiminh City University of Technology - VNU-HCM under the granted project number SVOISP-2016-MTTN-15.

\section{References}

Barber, S. A., Walker, J. M., \& Vasey, E. H. (1963). Mechanisms for Movement of Plant Nutrients from Soil and Fertilizer to Plant Root. Journal of Agricultural and Food Chemistry, 11, 204-207. https://doi.org/10.1021/jf60127a017 
Bautista, O. V., Fischer, G., \& Cárdenas, G. F. (2013). Cadmium and chromium effects on seed germination and root elongation in lettuce, spinach and Swiss chard. Agronomia Colombiana, 31(1), 48-57.

Dao, T. S., Le, T. H., Pham, T. L., Do-Hong, L. C., \& Nguyen, P. D. (2014). Influences of Cyanobacterial Toxins Microcystins on the Seedling of Plants. Journal of Environmental Protection, 5, 35-41. https://doi.org/10.4236/jep.2014.51005

Järup, L. (2003). British Medical Bulletin. Oxford Academic, 68(1), 167-182.

Jabłońska-Czapla, M., Nocoń, K., Szopa, S., \& Łyko, A. (2016). Impact of the Pb and Zn ore mining industry on the pollution of the Biała Przemsza River, Poland. Environmental Monitoring and Assessment, 188-262. https://doi.org/10.1007/s10661-016-5233-3

Jaishankar, M., Tseten, T., Anbalagan, N., Mathew, B. B., \& Beeregowda, K. H. (2014). Toxicity, mechanism and health effects of some heavy metals. Interdiscip Toxicol., 7(2), 60-72. https://doi.org/10.2478/intox-2014-0009

Li, W., Khan, M. A., Yamaguchi, S., \& Kamiya, Y. (2005). Effects of heavy metals on seed germination and early seedling growth of Arabidopsis thaliana. Plant Growth Regulation, 46, 45-50. https://doi.org/10.1007/s10725-005-6324-2

Nazir, R., Khan, M., Masab, M., Rehman, H. U., Rauf, N. U., Shahab, S., Ameer, N., Sajed, M., Ullah, M., Rafeeq, M., \& Shaheen, Z. (2015). Accumulation of Heavy Metals (Ni, Cu, Cd, $\mathrm{Cr}, \mathrm{Pb}, \mathrm{Zn}, \mathrm{Fe}$ ) in the soil, water and plants and analysis of physico-chemical parameters of soil and water Collected from Tanda Dam kohat. Journal of Pharmaceutical Science and Research, 7(3), 89-97.

Nguyen, V. T., \& Bui, T. N. (2009). The pollution of As, Cd in sediments, soil and water in the coastal area of Ca Mau Province (in Vietnamese). Cantho Journal of Science, 12, 15-24.

Ning, L., Liyuan, Y., Jirui, D., \& Xugui, P. (2011). Heavy Metal Pollution in Surface Water of Linglong Gold Mining Area, China. Procedia Environmental Sciences, 10, 914-917. https://doi.org/10.1016/j.proenv.2011.09.146

Obaidy, A. H., Mashhady, A. A., Awad, E. S., \& Kadhem, A. J. (2014). Heavy metals pollution in surface water of Mahrut River, Diyala, Iraq. International Journal of Advanced Research, 2(10), 1039-1044.

Sardar, K., Ali, S., Hameed, S., Afzal, S., Fatima, S., Bharwana, L., \& Tauqeer, H. M. (2013). Heavy metals contamination and what are the impacts on living organisms. Greener Journal of Environmental Management and Public Safety, 2(4), 172-179.

https://doi.org/10.15580/GJEMPS.2013.4.060413652

Shafiq, M., Zafar, I. M., \& Athar, M. (2008). Effect of lead and cadmium on germination and seedling growth of Leucaena leucocephala. Journal of Applied Sciences and Environmental Management, 12(2), 61-66.

Strady, E., Dinh, Q. T., Némery, J., Nguyen, T. N., Nguyen, G. S., Denis, H., \& Nguyen, P. D. 


\section{Macrothink}

(2017). Spatial variation and risk assessment of trace metals in water and sediment of the Mekong Delta. Chemosphere, 179, 367-378.

https://doi.org/10.1016/j.chemosphere.2017.03.105

Pflugmacher, S., Aulhorn, M., \& Grimm, B. (2007). Influence of a cyanobacterial crude extract containing microcystin-LR on the physiology and antioxidative defence systems of different spinach variants. New Phytologist, 175(3), 482-489.

https://doi.org/10.1111/j.1469-8137.2007.02144.x

Tiwaria, M. K., Bajpaia, S., Dewangana, U. K., \& Tamrakar, R. K. (2015). Assessment of heavy metal concentrations in surface water sources in an industrial region of central India. Karbala International Journal of Modern Science, 1(1), 9-14.

https://doi.org/10.1016/j.kijoms.2015.08.001

WHO/FAO/IAEA. (1996). Trace elements in human nutrition and health. Switzerland: Geneva: World Health Organization.

Wongklom, A. (2016). Non-volatile toxic heavy metals analysis in surface water collected from Moon and Shi rivers in Northeastern of Thailand by atomic absorption spectrophotometry. SNRU Journal of Science and Technology, 8(2), 275-283.

Wuana, R. A., \& Okieimen, F. F. (2011). Heavy Metals in Contaminated Soils: A Review of Sources, Chemistry, Risks and Best Available Strategies for Remediation. International Scholarly Research Notices, 20 pages. https://doi.org/10.5402/2011/402647

\section{Copyright Disclaimer}

Copyright for this article is retained by the author(s), with first publication rights granted to the journal.

This is an open-access article distributed under the terms and conditions of the Creative Commons Attribution license (http://creativecommons.org/licenses/by/3.0/). 